\title{
Invertebrates inhabiting temporary ponds found in the Tambo- Puquíos wet pasture (Andes of north-central Chile), and the physicochemical characteristics of their habitat
}

\author{
Invertebrados de pozas efímeras de la vega Tambo-Puquíos (Andes del norte-centro \\ de Chile) y las características fisicoquímicas de su hábitat
}

\author{
Jorge Cepeda-Pizarro ${ }^{1 *}$, Jaime Pizarro-Araya ${ }^{1}$, María C. Morales ${ }^{2}$
}

\begin{abstract}
The physical-chemical features of four temporary shallow ponds and their invertebrate fauna were studied during the summer months of three consecutive years. Invertebrate sampling was conducted by suction of pond water with a pump. From the physical-chemical point of view, the study ponds were heliotopic, mesotrophic and mesopoikilohaline microlimnotopes. Their thermal stratification is monomictic, with few degrees of difference in water temperature between surface and bottom. The chemical characteristics of pond water were in between those of freshwater and truly saline ponds. The study ponds exhibited high content of phosphate, Ca, and sulfate content, followed by fluoride, $\mathrm{Fe}, \mathrm{K}, \mathrm{Mg}, \mathrm{Cl}$, nitrate, and total suspended solids. They were low in bicarbonate and $\mathrm{CN}$ content. Apparently, the geochemical properties of the surrounding mountains play a role in the hydrochemistry of these water bodies. Total abundance per taxon was mostly low. We recorded five higher taxa. Cladocerans (e.g., Alona spp.), followed by dipterans (e.g., chironomid flies), and copepods (e.g., cyclopoids and harpactoids) were the dominant groups. Less abundant groups were amphipods (e.g., Hyperia spp.), and ostracods (e.g., Cyprididae). Some of the taxa reported in this work are recorded for first time in this type of habitat. Nevertheless, given the habitat characteristics, studies at finer taxonomic resolution are needed to search for site-specific genera or species. We obtained lower taxonomic richness compared to lotic systems found in the area. This result may be due to differences in the dynamics of abiotic conditions observed between the two habitats. The variability in abundance among ponds was high for most of the recorded taxa. This variability may be a reflection of the general condition of the wet pasture we studied, suggesting that the ponds are important sources of the high biodiversity found in these landscape units. As the wet pastures of the area are networked, also contribute to biodiversity of the entire mountain system. From this, it is clear that conservation strategies of Andean wet pastures need to include these small landscape units.

Key words: zooplankton, macroinvertebrates, temporary ponds, arid Andes, aquatic fauna, lentic habitats.
\end{abstract}

\section{RESUMEN}

Durante los meses de verano de tres años consecutivos se estudiaron las características fisicoquímicas de cuatro pozas efímeras, de poca profundidad y su fauna de invertebrados. El muestreo de los invertebrados se llevó a cabo por succión del agua con una máquina de bombeo. Desde el punto de vista fisicoquímico, las pozas estudiadas resultaron ser microlimnotopos heliotópicos, mesotróficos y mesopoikilohalinos. Su estratificación térmica resultó ser de carácter monomíctico, con pocos grados de diferencia térmica entre la superficie y el fondo. Se encontró que sus características químicas las sitúan entre hábitats dulceacuícolas y verdaderamente salinos. Las pozas mostraron alto contenido de fosfato, Ca y sulfato, seguido por los niveles de fluoruro, Fe, K, $\mathrm{Mg}, \mathrm{Cl}$ y nitrato. El contenido de los sólidos totales suspendidos fue igualmente alto. Por el contrario, el contenido de bicarbonato y CN fue bajo. Al parecer, las propiedades geoquímicas de las montañas que rodean a la vega juegan un papel importante en la hidroquímica de estos cuerpos de agua. En general, las abundancias totales por taxón fueron bajas. Se registraron cinco taxones superiores. Cladóceros (e.g., Alona spp.), seguido por los dípteros quironómidos y los copépodos ciclopoideos y harpacticoideos fueron los grupos dominantes. Grupos menos abundantes fueron los anfípodos (e.g., Hyperia spp.) y los ostrácodos Cyprididae. Algunos de los taxones reportados en este trabajo se registran por primera vez en este tipo de hábitat. Sin embargo, debido a sus características, se necesitan estudios con una resolución taxonómica más fina con el fin de dilucidar la presencia de géneros o especies propias de estos sistemas. En comparación con los cuerpos lóticos encontrados en la zona, las pozas arrojaron una menor riqueza taxonómica. Este resultado puede deberse a diferencias en la dinámica de las condiciones abióticas observadas entre los dos hábitats. La variabilidad entre pozas, asociada a la abundancia, fue alta para la mayoría de los taxones registrados. Esta variabilidad puede ser un reflejo de la condición general de la vega estudiada, lo que sugiere que estas pozas son fuente importante de la alta biodiversidad observada en estas unidades de paisaje. Como las vegas de la zona están conectadas en red, también contribuyen a la biodiversidad de todo el sistema de montaña. A partir de este argumento, resulta claro que las estrategias de conservación de las vegas andinas necesitan incluir a estas pequeñas unidades de paisaje.

Palabras clave: zooplancton, macroinvertebrados, pozas efímeras, Andes áridos, fauna acuática, hábitats lénticos.

1 Laboratorio de Entomología Ecológica, Depto. de Biología, Facultad de Ciencias, Universidad de La Serena, Casilla 599, La Serena, Chile.

2 Departamento de Acuicultura, Facultad de Ciencias del Mar, Universidad Católica del Norte, Larrondo 1281, Coquimbo, Chile

* Corresponding author: jcepeda@userena.cl

Fecha de Recepción: 23 Junio, 2013.

Fecha de Aceptación: 19 Agosto, 2015. 


\section{Introduction}

The geomorphologic heterogeneity of the highlands of northern Chile creates a mosaic of environmental conditions favorable for formation of habitats with highly contrasting features. In flat terrain, for instance, wet pastures ("vegas") ranging from less than one hectare to hundreds of hectares originate in places where water accumulates or emerges to the surface. Recently, the conservation status of these landscape units has triggered public awareness. This concern is because they are important water reservoirs and hotspots of local biological diversity in a rather poor mountain landscape. Presently, they are subjected to intense water consumption, heavy grazing, and exposed to possible effects of climate change (Fiebig-Wittmaack, 2014). To improve strategies for the conservation of these Andean landscape units it is necessary to broaden our knowledge about them. Their vegetation is relatively well known (e.g., Squeo et al., 1993, 2006a, 2006b), however knowledge about their fauna is much less. In the case of invertebrates, so far the available studies have focused on insects (e.g., Cepeda-Pizarro, 2013; Cepeda-Pizarro et al., 2015).

According to their levels of moisture and their plant characteristics, the wet pastures of the Andean transitional desert of Chile can be a continuous and semi dry carpet of short and cespitose vegetation, a semi-flooded wetland or a mixture of lawn, raised plant-cushions, small arroyos and ponds (Squeo et al., 2006b). These ponds are generally shallow, small, and ephemeral. Recently, water scarcity and biodiversity conservation have sparked considerable interest in the study of pond ecology all over the world (Oertli et al., 2009). Although preservation of large-scale wetlands seems to be warranted, it has led to a general neglect of small-scale landscape elements such as ponds. These environments may largely contribute to regional biodiversity because of their high local biological diversity, mainly by the compositional dissimilarity among sites (Jeffries, 2011). This contribution gains special importance in wetlands of arid lands (Williams, 1999). Despite this fact, knowledge about ecology of ephemeral and shallow Andean ponds remains scanty. For instance, one of the few available studies is that of Coronel et al. (2007), carried out in the Bolivian plateau.

The Tambo-Puquíos wet pasture is one of the better-known wet pastures of the Andes of north-central Chile. It is considered as a study case (Cepeda-Pizarro et al., 2006a, 2006b). The aims of the present study are to describe the ponds of the Tambo-Puquíos wet pasture as habitats for invertebrates and the invertebrate assemblage itself. This work is based on two ideas: (1) the ponds represent small aquatic islands surrounded by a carpet of vegetation in a rather poor mountain system (Coronel et al., 2007), and (2) they are usually temporary water bodies, subject to weather vagaries (Schwartz \& Jenkins, 2000).

\section{Materials and Methods}

\section{Study site and ponds}

The Tambo-Puquíos wet pasture (henceforth VTP) is located in the Andean section of the Elqui River basin at $3850-4000$ m elevation $\left(29^{\circ} 45^{\prime}\right.$ $\mathrm{S}, 69^{\circ} 59^{\prime} \mathrm{W}$ ) (Figure 1). The VTP gets its water from small streams that drain downslope from the surrounding arid mountains, from its own snow cover formed during wintertime and from subterranean water (Zavala, 2006). Located in a narrow valley, the VTP extends for $\sim 6 \mathrm{~km}$, with an area of $\sim 10 \mathrm{~km}^{2}$. Its vegetation is mainly composed of cespitose species such as Calandrinia compacta (Portulacaceae), Carex maritime (Cyperaceae), Pucinellia oresigena (Gramineae), Deschampsia caespitosa (Gramineae) and Deyeuxia velutina (Gramineae). This array of vegetation includes several small and shallow ponds, some of them temporary water regimes (Figure 2). The aquatic vegetation is represented by the microalgae Cryptomonas and Rhodomonas and the filamentous algae Oscillatoria and Microthamnion. Common aquatic vascular plants are Potamogeton strictus (Potamogetonaceae), Myriophyllum quitense (Haloragaceae) and Ranunculus chilensis (Ranunculaceae). Organic debris, including fecal pellets from aquatic birds, is usually present in the pond bed (Cepeda-Pizarro et al., 2006a). These ponds lack fish and amphibians (Cepeda-Pizarro et al., 2006b). The avifauna are for the most part summer visitors. The most commonly found aquatic birds are the crested duck (Lophonetta specularioides), the Chilean teal (Anas flavirostris) and the Andean goose (Chloephaga melanoptera) (Tabilo, 2006). To carry out the study we selected four ponds as replicates (Figure 3, Table 1). Sampling for both the invertebrate assemblage and for the physicalchemical characterization of the ponds was done in summer (January or February). 


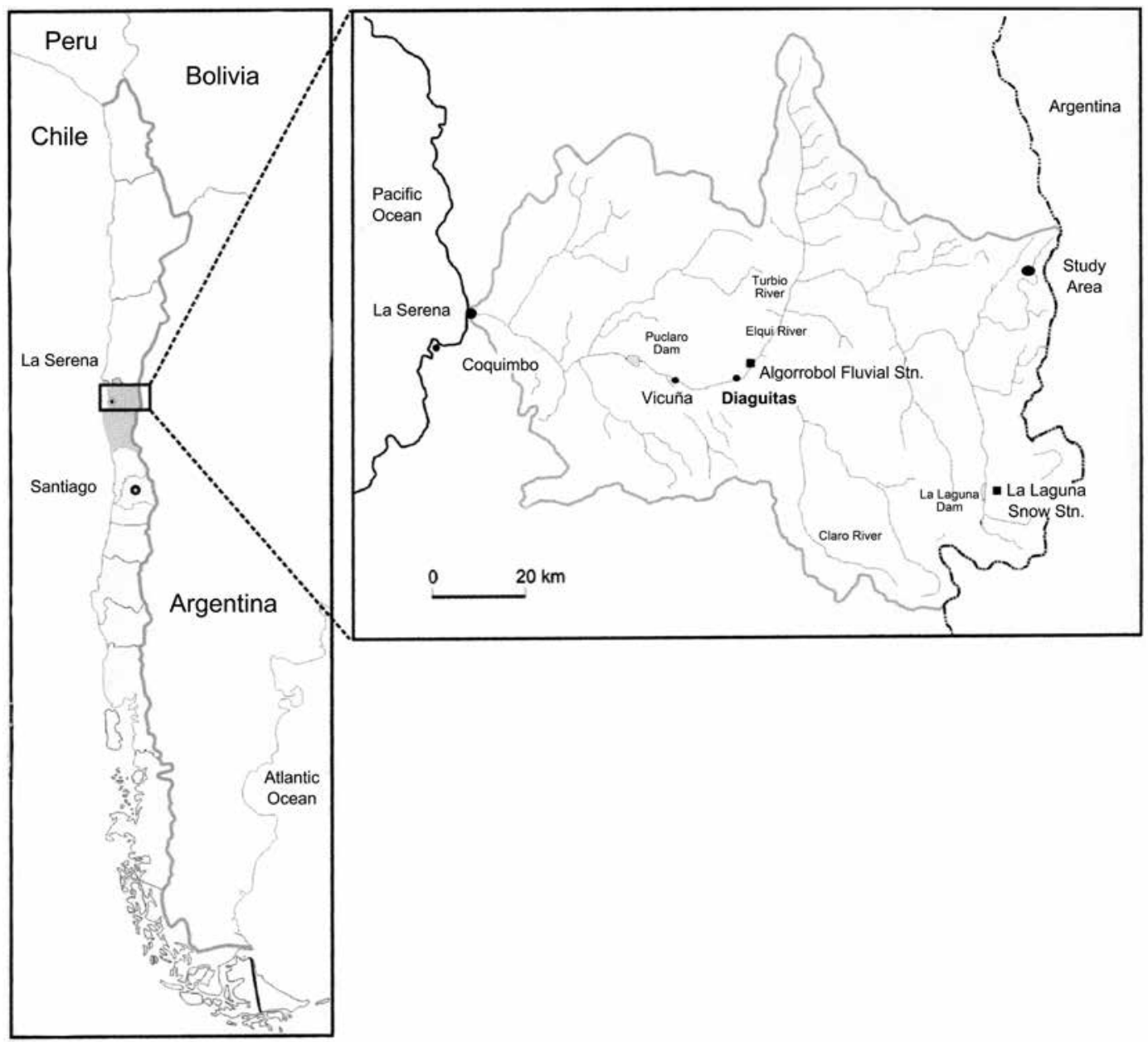

Figure 1. Geographic location of the study site ( ) (2945’ S, 6959’ W).

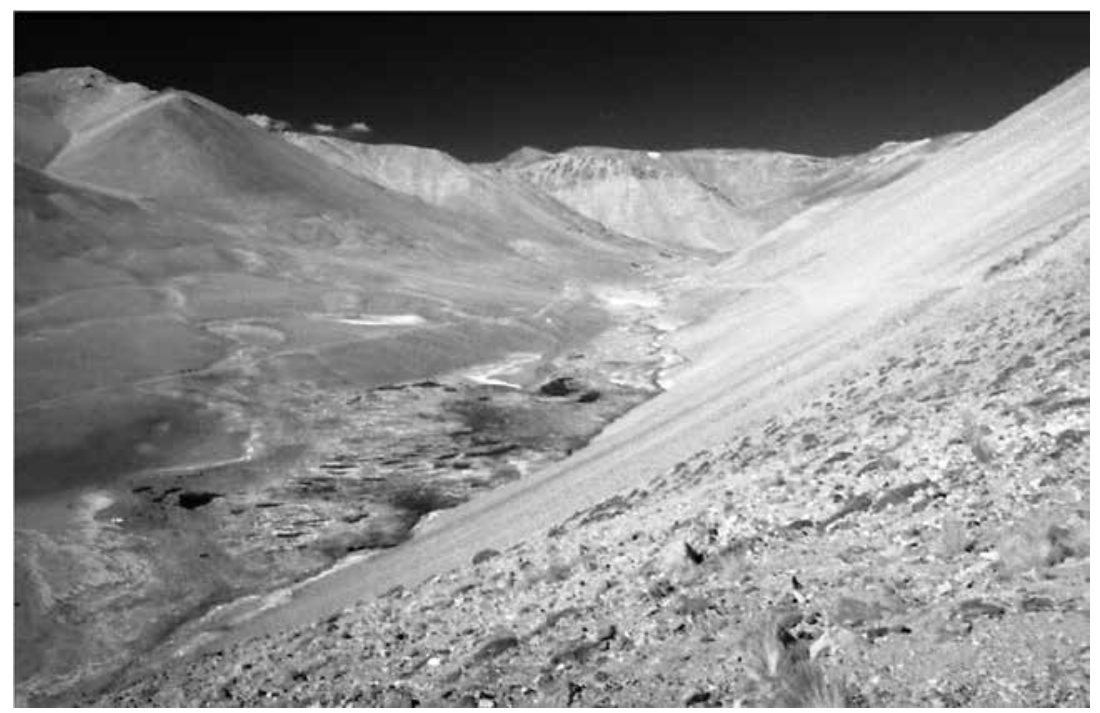

Figure 2. General view of study wet-pasture ( $3850 \mathrm{~m}$ elevation). The darker patches correspond to shallow temporary ponds. The clear spots in the peatland and its margins are sulfate crusts. 


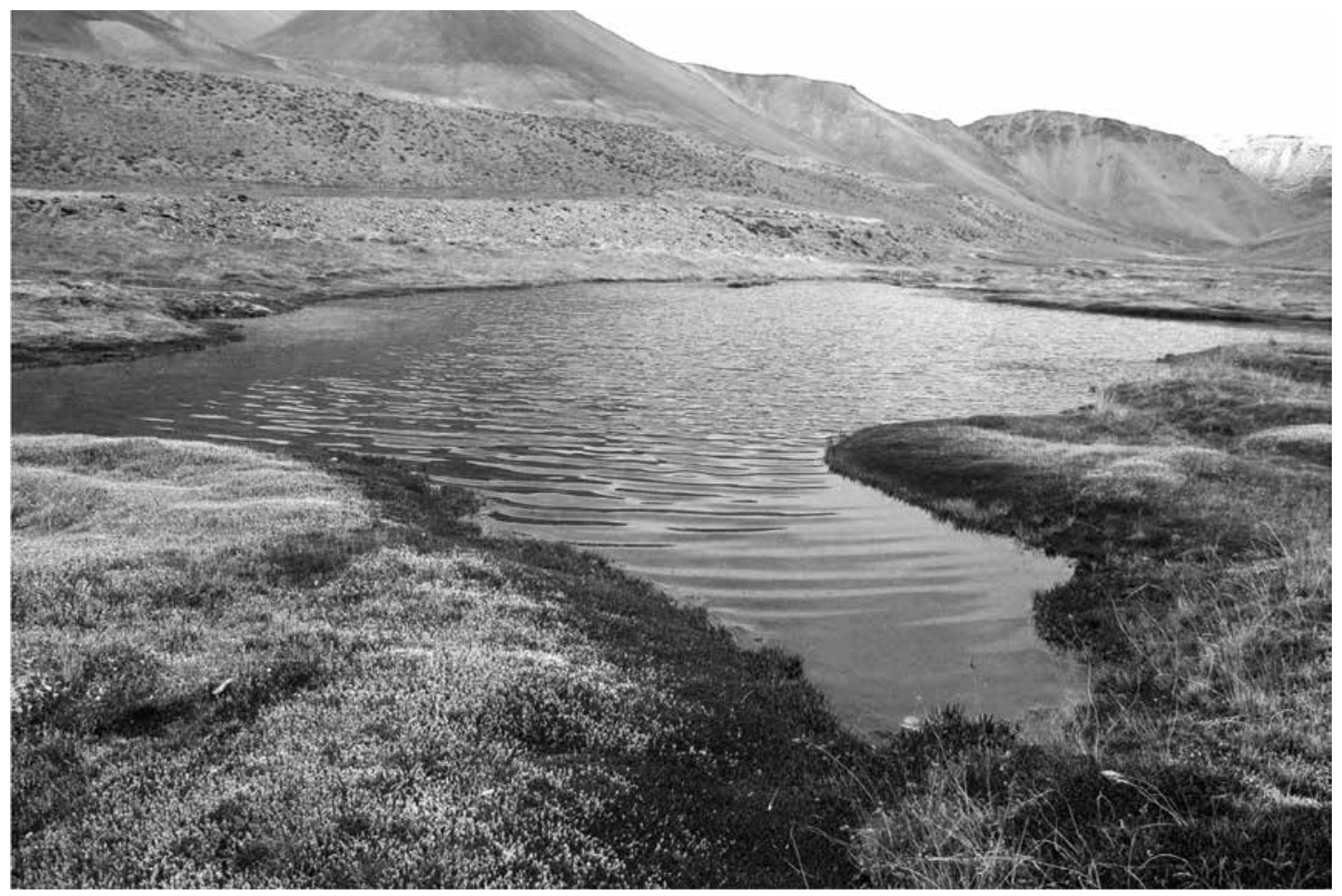

Figure 3. Close-up of one of the study ponds, with sulfate deposits on its borders.

Table 1. Some characteristics of the study ponds. For vegetation description see the paragraph study site and ponds (material and methods section).

\begin{tabular}{|c|c|c|c|c|}
\hline Feature & Pond 1 & Pond 2 & Pond 3 & Pond 4 \\
\hline Shape & elongated & ovoid & L-shaped & ovoid \\
\hline Length & 18.5 m; & $12.3 \mathrm{~m}$ & $\begin{array}{l}\text { Length large arm: } 27.5 \\
\text { Length short arm: } 14.0 \mathrm{~m}\end{array}$ & $58.7 \mathrm{~m}$ \\
\hline Maximum width & $4.0 \mathrm{~m}$ & $58.0 \mathrm{~m}$ & as above & $27.3 \mathrm{~m}$ \\
\hline Mean depth & $0.3 \mathrm{~m}$ & $0.5 \mathrm{~m}$ & $0.2 \mathrm{~m}$ & $0.3 \mathrm{~m}$ \\
\hline Surface (approx.) & $43.8 \mathrm{~m}^{2}$ & $43.7 \mathrm{~m}^{2}$ & $162.5 \mathrm{~m}^{2}$ & $1250.0 \mathrm{~m}^{2}$ \\
\hline Bottom & $\begin{array}{l}\text { without vegetation, } \\
\text { muddy-black }\end{array}$ & $\begin{array}{l}\text { without vegetation, } \\
\text { muddy-black }\end{array}$ & $\begin{array}{c}\text { covered by aquatic } \\
\text { vegetation }\end{array}$ & $\begin{array}{c}\text { covered by aquatic } \\
\text { vegetation }\end{array}$ \\
\hline Vegetation & $\begin{array}{l}\text { scarce presence of } \\
\text { filamentous algae and } \\
\text { some vascular plants. }\end{array}$ & $\begin{array}{l}\text { scarce presence of } \\
\text { filamentous algae and } \\
\text { some vascular plants }\end{array}$ & $\begin{array}{l}\text { abundance of filamentous } \\
\text { algae and vascular plants; } \\
\text { borders of pond with } \\
\text { abundant fecal depositions } \\
\text { of aquatic birds. }\end{array}$ & $\begin{array}{l}\text { abundant presence of } \\
\text { filamentous algae and } \\
\text { vascular plants. }\end{array}$ \\
\hline
\end{tabular}

\section{Invertebrate habitat characterization}

Water sampling and analyses were conducted by a specialized contractor in accordance with standard techniques (APHA et al., 1985). The physical parameters examined were total hardness, electrical conductivity, turbidity, alkalinity, total dissolved solids, total suspended solids, and total solids. The chemical parameters examined were
$\mathrm{pH}$, dissolved metals, inorganic nonmetallic ions and the trace elements $\mathrm{Al}$, total $\mathrm{As}, \mathrm{Ba}, \mathrm{Cu}, \mathrm{B}, \mathrm{Cd}$, $\mathrm{Co}, \mathrm{Cr}, \mathrm{Fe}, \mathrm{Pb}, \mathrm{Li}, \mathrm{Ni}, \mathrm{Zn}$, and $\mathrm{CN}$.

\section{Invertebrate assemblage}

Invertebrate sampling was conducted for three consecutive years (1997-1999). Two samples (50 L each) per pond were collected in each sampling 
period. Samples were obtained by sucking water by means of a 2 -in pump connected to a hosepipe ( $5 \mathrm{~cm}$ in diameter and $7 \mathrm{~m}$ long) that acted as a sucker. During suction, the water intake was moved throughout the pond to insure a homogenous sampling effort. The trapped water was then deposited in ad hoc containers until the required volume $(50 \mathrm{~L})$ was obtained. The water was filtered through a 1-mm mesh in order to remove algal clots and organic debris. The specimens trapped in algal clots and organic debris were separated by washing the clots and the debris with boiled tap water. The sample was concentrated by filtering it through a $45-\mu \mathrm{m}$ mesh. The remaining material was removed from the mesh and preserved in a mixture of 1:9 glycerin-ethanol $\left(70^{\circ}\right)$, transported to the laboratory and stored at $<10^{\circ} \mathrm{C}$ until isolation, identification, and counting. Before isolating the specimens, each sample was filtered through a series of meshes of different pore sizes (i.e., 800, 600, 300, 125, 100 , and $45 \mu \mathrm{m}$ ) following Makoto \& Tsutomo (1976), to obtain subsamples sorted by specimen size. The sub-sampling was done using tap water. Counting was done without dilution for the first two subsamples; afterwards, the subsamples were taken to a volume of $50 \mathrm{ml}$, split into four aliquots and then quantified. Counting was conducted using both a Bogorov-open chamber and a reticular grid. Taxonomic identification was made following Villalobos (2006) and De los Ríos-Escalante et al. (2013). In all cases, density is expressed as individuals per liter (ind $\mathrm{L}^{-1}$ ).

\section{Results}

\section{Habitat characterization}

Although they were considered temporary, none of the ponds dried up during the study; their depths changed slightly by $0.2-0.3 \mathrm{~m}$. According to the time of day, the air mean temperature of pond water varied from $5{ }^{\circ} \mathrm{C}$ in the mid-morning, when it was $2-3{ }^{\circ} \mathrm{C}$ below air-temperature, to $15^{\circ} \mathrm{C}$ in the mid-afternoon, when it was $2-3{ }^{\circ} \mathrm{C}$ above airtemperature. The water temperature tended to be slightly higher near the bottom than at the surface. Details of physical and chemical features of the pond water are provided in Table 2. Pond water was generally transparent, very hard, strongly saline, high in TDS and moderately high in oxygen. The dominant metal ions were $\mathrm{Ca}, \mathrm{Na}, \mathrm{Mg}$, and $\mathrm{K}$. The
Table 2. Mean (mg L-1 \pm s.e.) of some limnetic parameters of study ponds.

\begin{tabular}{|c|c|c|}
\hline \multirow[b]{2}{*}{ 1. Physical variables } & \multicolumn{2}{|c|}{ Mean \pm s.e. } \\
\hline & & \\
\hline Total hardness $\left(\mathrm{mg} \mathrm{L}^{-1} \mathrm{CaCO}_{3}\right)$ & 556.5 & $\pm(490.0)$ \\
\hline Conductivity $\left(\mu \mathrm{Scm}^{-1}\right)$ & 1678 & \\
\hline Turbidity (n.t.u.) & 8.9 & $\pm(4.2)$ \\
\hline Alkalinity $\left(\mathrm{mg} \mathrm{CaCO}_{3} \mathrm{~L}^{-1}\right)$ & 130.9 & $\pm(19.9)$ \\
\hline $\operatorname{TDS}\left(\mathrm{mg} \mathrm{L}^{-1}\right)\left(\mathrm{a} 105^{\circ} \mathrm{C}\right)$ & 1229.5 & - \\
\hline Total solids (mg L-1) & 1806.0 & $\pm(134.8)$ \\
\hline Suspended solids (mg L${ }^{-1}$ ) & 127.7 & $\pm(23.1)$ \\
\hline \multicolumn{3}{|l|}{ 2. Chemical variables } \\
\hline $\mathrm{pH}$ & 8.5 & $\pm(0.5)$ \\
\hline Dissolved $\mathrm{O}_{2}\left(\mathrm{mgO}_{2} / \mathrm{L}^{-1}\right)$ & 9.7 & - \\
\hline $\mathrm{Al}\left(\mathrm{mg} \mathrm{L}^{-1} \mathrm{Al}\right)$ & 0.5 & - \\
\hline Total As (mg L-1 As) & 0.3 & - \\
\hline $\mathrm{Cd}\left(\mathrm{mg} \mathrm{L}^{-1} \mathrm{Cd}\right)$ & $<0.0$ & - \\
\hline $\mathrm{Ca}\left(\mathrm{mg} \mathrm{L}^{-1} \mathrm{Ca}\right)$ & 204.8 & $\pm(45.7)$ \\
\hline Total CN (mg L $\left.{ }^{-1} \mathrm{CN}\right)$ & 0.1 & - \\
\hline Bicarbonate $\left(\mathrm{mg} \mathrm{CaCO}_{3} \mathrm{~L}^{-1}\right)$ & 10.9 & $\pm(4.6)$ \\
\hline $\mathrm{Cu}\left(\mathrm{mg} \mathrm{L}^{-1} \mathrm{Cu}\right)$ & $<0.0$ & - \\
\hline Total $\mathrm{Cr}\left(\mathrm{mg} \mathrm{L}^{-1} \mathrm{Cr}\right)$ & 0.1 & - \\
\hline $\mathrm{Fe}\left(\mathrm{mg} \mathrm{L}^{-1} \mathrm{Fe}\right)$ & 0.3 & - \\
\hline $\mathrm{Mn}\left(\mathrm{mg} \mathrm{L}^{-1} \mathrm{Mn}\right)$ & 2.4 & - \\
\hline $\mathrm{Mg}\left(\mathrm{mg} \mathrm{L}^{-1} \mathrm{Mg}\right)$ & 59.7 & - \\
\hline $\mathrm{Fl}\left(\mathrm{mg} \mathrm{L}^{-1} \mathrm{~F}\right)$ & 1.3 & $\pm(0.3)$ \\
\hline Sulfate $\left(\mathrm{mg} \mathrm{L}^{-1} \mathrm{SO}_{4}\right)$ & 975.6 & $\pm(36.3)$ \\
\hline $\mathrm{Ba}\left(\mathrm{mg} \mathrm{L}^{-1} \mathrm{Ba}\right)$ & 0.5 & - \\
\hline $\mathrm{Be}\left(\mathrm{mg} \mathrm{L}^{-1} \mathrm{Be}\right)$ & 0.1 & - \\
\hline $\mathrm{B}\left(\mathrm{mg} \mathrm{L}^{-1} \mathrm{~B}\right)$ & 1.9 & - \\
\hline $\mathrm{Co}\left(\mathrm{mg} \mathrm{L}^{-1} \mathrm{Co}\right)$ & 0.0 & - \\
\hline $\mathrm{Cl}\left(\mathrm{mg} \mathrm{L}^{-1}\right)$ & 34.2 & - \\
\hline $\mathrm{Zn}\left(\mathrm{mg} \mathrm{L}^{-1} \mathrm{Zn}\right)$ & $<0.0$ & - \\
\hline Mo (mg L-1 Mo) & $<0.0$ & - \\
\hline $\mathrm{Hg}\left(\mathrm{mg} \mathrm{L}^{-1} \mathrm{Hg}\right)$ & $<0.0$ & - \\
\hline $\mathrm{Ni}\left(\mathrm{mg} \mathrm{L}^{-1} \mathrm{Ni}\right)$ & 0.1 & - \\
\hline $\mathrm{Pb}\left(\mathrm{mg} \mathrm{L}^{-1} \mathrm{~Pb}\right)$ & $<0.0$ & - \\
\hline $\mathrm{Li}\left(\mathrm{mg} \mathrm{L}^{-1} \mathrm{Li}\right)$ & 0.8 & - \\
\hline $\mathrm{Ag}\left(\mathrm{mg} \mathrm{L}^{-1} \mathrm{Ag}\right)$ & $<0.0$ & - \\
\hline $\mathrm{V}\left(\mathrm{mg} \mathrm{L}^{-1} \mathrm{~V}\right)$ & 0.1 & - \\
\hline $\mathrm{K}\left(\mathrm{mg} \mathrm{L}^{-1} \mathrm{~K}\right)$ & 12.8 & $\pm(3.6)$ \\
\hline $\mathrm{Na}\left(\mathrm{mg} \mathrm{L}^{-1} \mathrm{Na}\right)$ & 159.5 & - \\
\hline $\mathrm{Na}(\%)$ & 47.5 & - \\
\hline $\mathrm{Se}\left(\mathrm{mg} \mathrm{L}^{-1} \mathrm{Se}\right)$ & 0.0 & - \\
\hline Nitrate $\left(\mathrm{mg} \mathrm{N} \mathrm{L}^{-1}\right)$ & 3.3 & $\pm(2.6)$ \\
\hline Nitrite $/\left(\mathrm{mg} \mathrm{L}^{-1}\right)$ & $<0.0$ & \\
\hline Phosphate (mg L-1) & 22.4 & $\pm(30.9)$ \\
\hline
\end{tabular}


Table 3. Mean abundance (ind/L-1) of taxonomic groups of invertebrates in study ponds*.

\begin{tabular}{lrr}
\hline Taxon & Mean \pm s.e. & Relative (\%) \\
\hline Cladocera: & & \\
Daphnia spp. (Daphnidae) & $3.6 \pm 1.8$ & 3.8 \\
Alona spp. (Chydoridae) & $53.4 \pm 12.4$ & 56.9 \\
Copepoda: & & \\
& & \\
Eucyclops spp. (Cyclopidae) & $11.9 \pm 9.6$ & 12.7 \\
Attheyella spp. (Canthocamptidae) & $1.7 \pm 2.4$ & 1.8 \\
Amphipoda: & & \\
& & \\
Hyalella spp. (Hyallelidae) & $0.3 \pm 0.2$ & 0.3 \\
Hyperia spp. (Hyperiidae). & $1.0 \pm 1.4$ & 1.0 \\
Ostracoda: & & \\
Hemicypris spp. (Cyprididae) & $0.1 \pm 0.0$ & 0.1 \\
Insecta: & & \\
Corixidae & & \\
Chironomidae (larvae) & $3.4 \pm 0.52$ & 3.6 \\
Mean & $18.4 \pm 12.6$ & 19.8 \\
\hline
\end{tabular}

*Taxonomic nomenclature follows Villalobos (2006) and De los Ríos-Escalante et al. (2013). Mean obtained from four ponds, three years of sampling. Percent dominance $=$ mean taxon i/ grand mean.

dominant inorganic non-metal ions were sulfate, chloride, phosphate, and bicarbonate. The content of sulfate $+\mathrm{Ca}$ accounted for $96 \%$ of total dissolved solids. The $\mathrm{Mg} / \mathrm{Ca}$ relationship was close to 0.3 . Ponds showed the presence of $\mathrm{Al}, \mathrm{As}, \mathrm{Ba}, \mathrm{Be}, \mathrm{B}$,
$\mathrm{Cd}, \mathrm{Co}, \mathrm{Cr}, \mathrm{Fe}, \mathrm{Pb}, \mathrm{Li}, \mathrm{Mn}, \mathrm{Mo}, \mathrm{Ni}, \mathrm{Ag}, \mathrm{V}$, and $\mathrm{Zn}$, but no $\mathrm{Hg}$, Se or nitrite. The sequence of trace element content was $\mathrm{B}>\mathrm{Li}>\mathrm{Al}=\mathrm{Ba}>\mathrm{As}=\mathrm{Fe}>$ $\mathrm{Cr}=\mathrm{Ni}>\mathrm{Co}>\mathrm{Pb}>\mathrm{Cu}>\mathrm{Cd}=\mathrm{Zn}>\mathrm{CN}$.

\section{Invertebrate assemblage}

The abundance and richness of invertebrates were rather low (Table 3). No mollusks (e.g., snails) were found. Dominant higher taxa were represented by five taxa of Arthropoda, clearly dominated by Cladocera $(60.7 \%)$, followed by Insecta $(23.3 \%)$ and Copepoda (14.5\%). Less abundant taxa were Amphipoda (1.3\%) and Ostracoda (0.1\%). At lower taxonomic resolution, the highest abundance corresponded to Alona sp. (56.9\%), followed by Chironomidae (19.7\%) and Eucyclops sp. (12.7 $\%$ ) Dominance of these taxa remained stable across the study years (Table 4 ).

\section{Discussion}

Typologically, the study ponds are heliotopic, mesotrophic, and mesopoikilohaline microlimnotopes (Ringuelet, 1962). Their thermal stratification is monomictic, with few degrees difference between surface and bottom. The frequent strong winds and convective currents that occur during nocturnal cooling facilitate water overturn (Cepeda-Pizarro $\&$ Novoa, 2006). The characteristics of pond water are in between those of freshwater and truly saline

Table 4. Annual variation and variability among samples (CV) of relative abundance* of invertebrates inhabiting temporary ponds located in the Tambo-Puquíos wet pasture (2945' S, 6959' W; Andean transitional desert of Chile).

\begin{tabular}{|c|c|c|c|c|c|c|c|c|c|}
\hline \multirow{2}{*}{ Taxon } & \multicolumn{3}{|c|}{1997} & \multicolumn{3}{|c|}{1998} & \multicolumn{3}{|c|}{1999} \\
\hline & Mean & s.e. & $\mathrm{CV}$ & Mean & s.e. & $\mathrm{CV}$ & Mean & s.e. & $\mathrm{CV}$ \\
\hline Alona spp. & 57.4 & \pm 45.4 & 126.3 & 83.4 & \pm 55.0 & 151.6 & 81.6 & \pm 51.7 & 158.0 \\
\hline Daphnia spp. & 0.1 & \pm 0.1 & 86.5 & 0.3 & \pm 0.2 & 129.5 & 0.4 & \pm 0.4 & 120.0 \\
\hline Hyperia spp. & 10.4 & \pm 26.1 & 40.0 & 38.9 & \pm 46.6 & 83.3 & 29.2 & \pm 30.2 & 96.9 \\
\hline Hyalella spp. & 0.3 & \pm 0.3 & 110.5 & 0.5 & \pm 0.4 & 129.9 & 0.8 & \pm 0.7 & 113.8 \\
\hline Hemicypris spp. & 0.1 & \pm 0.2 & 35.4 & 0.1 & \pm 0.3 & 43.6 & 0.4 & \pm 0.7 & 55.4 \\
\hline Eucyclops spp. & 11.9 & \pm 17.9 & 66.2 & 14.8 & \pm 21.6 & 68.6 & 8.8 & \pm 6.3 & 140.4 \\
\hline Attheyella spp. & 1.7 & \pm 3.2 & 53.8 & 2.2 & \pm 4.0 & 54.5 & 1.4 & \pm 2.4 & 55.3 \\
\hline Corixidae & 2.4 & \pm 1.4 & 175.0 & 3.5 & \pm 1.4 & 241.7 & 4.2 & \pm 2.3 & 178.9 \\
\hline Chironomidae & 18.4 & \pm 13.0 & 141.1 & 16.8 & \pm 11.1 & 151.3 & 47.1 & \pm 20.2 & 233.7 \\
\hline
\end{tabular}

*Mean abundance as ind/L-1. 
ponds. Compared to data reported in the literature for natural lentic fresh-waters (e.g. Chapman, 1996), the study ponds are much higher in phosphate, $\mathrm{Ca}$, and sulfate content, and higher in fluoride, $\mathrm{Fe}$, $\mathrm{K}, \mathrm{Mg}, \mathrm{Cl}$, nitrate and total suspended solids, but lower in bicarbonate and $\mathrm{CN}$ content. Apparently, the geochemical properties of the surrounding mountains play a role in the hydrochemistry of these water bodies as documented by early work conducted in the area (Veit, 1993), in accordance with studies carried out in other latitudes (e.g., López et al., 1999). In our case, the high content of sulfate in the study ponds can be explained by the abundance of native sulfur in the area and the active hydrothermal mineralization (Oyarzún et al., 2004).

Chile currently lacks taxonomic expertise for most of the groups of invertebrates inhabiting the Andean waters, and taxonomic resolution of the studies is frequently low (Villalobos, 2006; De los Ríos-Escalante et al., 2013; Alvial et al., 2014). The present study faced this problem as well. Therefore, the presence of the genera communicated in this report should be viewed with caution until confirmed by further taxonomic work, which is currently being carried out. The literature indicates that freshwater ponds are usually dominated numerically by microcrustaceans and insects of the orders Coleoptera (e.g., Dytiscidae, Hydrophilidae), Diptera (Chironomidae), Hemiptera (Corixidae) and Trichoptera (Florencio et al., 2009; Jeffries, 2011). Except for Chironomidae and Corixidae, we did not find the remaining taxa of Insecta reported as common in fresh waters. Similarly, compared to streams of the area (Alvial et al., 2014) our study ponds were quite low in insect richness. Chironomidae is a conspicuous family of Diptera found in freshwater lentic habitats, both at low and highlands (Jeffries, 2011). They can become an abundant and diverse group in harsh environments (Oliver \& Dillon, 1997). For example, Márquez-García et al. (2009) report the presence of Chironomidae in saline water bodies of the southern Altiplano, and Alcocer et al. (2001) for a saline lake of Central Mexico. In the wet pastures we studied, Chironomidae is one of the most abundant families of Insecta (CepedaPizarro et al., 2006b). Despite its conspicuousness, taxonomic knowledge of the Andean Chironomidae is quite poor at the specific level (Cepeda-Pizarro et al., 2015).

Inland waters of north-central Chile appear to have low microcrustacean richness (De los
Ríos-Escalante et al., 2013). Our study ponds and the small streams of the area repeat this pattern (Alvial et al., 2014). We did not find Anostraca in our study ponds; however, we report the presence of Daphnids and Chidorids as representatives of Cladocera: Alona sp. is probably Alona affinis, the dominant species. Another dominant taxon found in the study ponds was Copepoda, probably represented by Eucyclops sp. (Eucyclopidae) and Attheyella sp. (Canthocamptidae). Less abundant taxa were Hyperia sp (Hyperiidae), Hyalella spp. (Hyalellidae), and Hemicypris spp. (Cyprididae). Márquez-García et al. (2009) have reported the genus Alona from Altiplano ponds, De los Ríos (2005) from northern Andean Chile and Echaniz et al. (2006) from saline lakes of the Argentinean Pampa. Moreover, although Amphipoda is reported as dominant group in oligosaline wetlands (500-5000 $\mathrm{mg} \mathrm{L}^{-1}$ TDS) (Hart \& Loworn, 2005), the literature on Andean saline ponds does not mention it as a common taxon except for Dejoux (1993), who reports Amphipoda as one of dominant taxa in freshwater tributaries of saline lakes in the Bolivian Altiplano. De los Ríos (2005) also mentions the presence of cyclopoid copepods in water bodies located in the Andes of northern Chile. The invertebrate fauna of specific habitats such as our study ponds can diverge from patterns found in most fresh waters. For instance, although taxonomic richness is low in saline ponds, they are richer in specialized fauna (De los Ríos \& Crespo, 2004; De los Ríos, 2005; Echaniz et al., 2006; Márquez-García et al., 2009). For the time being we are unfortunately unable to inform whether the ponds host site-specific forms of insects and microcrustaceans.

Given the characteristics of the Andes Range of north-central Chile (Cepeda-Pizarro \& Novoa, 2006), the ponds may represent a rather harsh environment for the inhabiting biota. As pointed out by Dorador et al., (2003), the ponds' hydroperiod and the physical-chemical characteristics of the water are expected to be the most important environmental factors shaping the assemblage of invertebrates. The effects of the physical-chemical characteristics have been more widely reported in the literature than the effects of hydroperiods (Florencio et al., 2009). For instance, Timms (1983), studying shallow saline waterbodies of Western Australia, reported that many groups contribute to the standing crop at low to moderate salinities, but crustaceans become important at high salinities. At higher salinities, 
the invertebrate fauna becomes depauperate, with dominance of a few well-adapted species (De los Ríos \& Crespo, 2004). However, salinity is not the only factor mentioned to play a role. Indeed, López et al. (1999) showed that salinity along with total dissolved solids, electrical conductivity, and $\mathrm{pH}$ explained a high proportion of abundance of plankton community inhabiting ponds found in salt flats of northern Chile. Dissolved oxygen, $\mathrm{pH}$, ionic composition, water transparency, total $\mathrm{N}$, inter-site distances and pond depth are also mentioned (Echaniz et al., 2006; Márquez-García et al., 2009). On the same grounds, the physical-chemical features of mountain streams found in two watersheds of the southern Atacama Desert have been used to explain the differences observed in their aquatic invertebrate communities (Alvial et al., 2014). We believe that the low abundance and taxonomic poorness of invertebrates observed in our study ponds are due to both physical and chemical factors. Among these are the environmental temperature fluctuations (both daily and seasonal), the relative isolation of the wet pasture and the physical-chemical features of pond water, in accordance with studies conducted in nearby watersheds (Ginocchio et al., 2008).

Although the four ponds we studied were in the same wet pasture, they were relatively separated from each other. As documented by former work (Alvial et al., 2014 Cepeda-Pizarro \& Armijo, 2014), the water bodies of the area show high spatial variability in their physical-chemical characteristics. This high spatial variability is a phenomenon commonly found in water bodies of arid and semiarid zones (Williams, 1996). This variability may be responsible for the spatial variability in abundance of invertebrates observed in this research. Recently, Briers \& Biggs (2005) pointed out that both the spatial pattern in physical-chemical conditions and the physical distance between ponds influence the spatial pattern of community composition, reflecting larger features of the landscape. Following Jeffries (2008), we suspect that the environmental heterogeneity of the system of wet pastures present in the Andean transitional desert of Chile (Squeo et al., 2006b; Osorio et al., 2006) must be very high, where it can become the most important generator of biodiversity. Unfortunately, there is no previous work on this line of reasoning to document this assertion. Declerck et al. (2011) advanced the idea that in ecosystems such as those studied here there is scale dependency in the processes that structure meta-communities such as the ones found in the network of wet pastures found in the highland of the Elqui river basin, with environmental control stronger at the smallest spatial scale. From above, it becomes clear that to preserve the biota at a landscape level, it is necessary to draw attention to these small-scale systems for their own specific characteristics (Schwartz \& Jenkins, 2000).

In summary, we recorded few invertebrate taxa. This may be a general case for ponds of the Andean transitional desert of Chile. High contents of total solids, sulfate, and Ca characterize the water of the ponds located in the Tambo-Puquíos wet pasture system. Spatial variability in water quality is also high. Along with vagaries of the arid mountain climate, these features can set severe restrictions on the colonizers of ponds. Based on these characteristics, many of these ponds seem to be in a permanent state of immaturity. This scenario forces invertebrates to be in a constant state of recolonization (Frisch \& Green, 2007). Given the arid climate and altitude of the site, this process takes place in a temporal framework dominated by not only significant intra-annual variations but also by strong inter-annual variations (Florencio et al., 2009). The low diversity and reduced abundance of invertebrates observed in this study, with clear dominance of few well adapted taxa, may reflect this dynamics.

\section{Acknowledgements}

$H$. Vasquez designed and operated the sampling device in the field. This study was funded by the Research Office of the University of La Serena, La Serena, Chile (PAR-12 to J. Cepeda-Pizarro and PR13121 to J. Pizarro-Araya). 


\section{Literature Cited}

Alcocer, J.; Escobar, E.G.; Lugo, A.; Lozano, M.; Oseguera, L.A. 2001. Benthos of a seasonally-astatic, saline, soda lake in Mexico. Hydrobiologia, 466: 291-297.

Alvial, I.E.; Verdugo, C.; Squeo, F.A.; Tapia, D.

2014. Ecology and Environmental Issues of Aquatic Invertebrates in High Mountains Rivers of Northern Chile. In: Mountains: Geology, Topography and Environmental. Goncalves A.J.B.; Vieira, A.A.B. (eds.). Concerns, Publisher: Nova Science Publishers, Inc, Editors, New York, USA. pp. 229-249.

APHA; AWWA; WPCF.

1985. Standard Methods for the Examination of Water and Wastewater. American Public Health Association American (APHA), American Water Works Association (AWWA) \& Water Pollution Control Federation (WPCF). 16th edition. Washington D.C. 541 p.

Briers, R.A.; Biggs, J.

2005. Spatial patterns in pond invertebrate communities: separating environmental and distance effects. Aquatic Conservation: Marine and Freshwater Ecosystems, 15: 549-557.

Cepeda-Pizarro, J.

2013. Variabilidad temporal de algunos parámetros físicos e hidroquímicos de un prado húmedo alto-andino del nortecentro de Chile. Idesia, 31: 89-97.

Cepeda-Pizarro, J.; Novoa, J.J.

2006. La cordillera alto andina del Valle del Elqui. In: Geoecología de los Andes desérticos. La alta montaña del Valle del Elqui. Cepeda-Pizarro, J. (ed.). Ediciones Universidad de La Serena. La Serena, Chile, pp. 41-63.

Cepeda-Pizarro, J.; Armijo, A.A.

2014. Dinámica fluviométrica y limnológica de un cuerpo superficial de agua asociado a un prado húmedo de los Andes del norte-centro de Chile. Idesia, 32: 11-19.

Cepeda-Pizarro, J.; Pola, M.; González, C.R.

2015. Efecto de la fase fenológica de verano sobre algunas características del ensamble de Diptera registrado en una vega altoandina del desierto transicional de Chile. Idesia, 33: 49-58.

Cepeda-Pizarro, J.; Pola, M.; Zuleta C.; González, C.R.

2006a. Relaciones de abundancia y diversidad de la entomofauna del humedal Tambo-Puquíos. In: Geoecología de los Andes desérticos. La alta montaña del Valle del Elqui. CepedaPizarro, J. (ed.). Ediciones Universidad de La Serena. La Serena, Chile, pp. 475-521.

Cepeda-Pizarro, J.; Squeo, F.A.; Cortés, M.; Oyarzún, J.; Zavala. H. 2006b. La biota del humedal Tambo-Puquíos. In: Geoecología de los Andes desérticos. La alta montaña del Valle del Elqui. Cepeda-Pizarro, J. (ed.). Ediciones Universidad de La Serena. La Serena, Chile, pp. 243-283.

Cereghino, R.; Bigss, J.; Oertli B.; Declerck, S.

2008. The ecology of European ponds: defining the characteristics of a neglected freshwater habitat. Hydrobiologia, 597: 1-6.

Chapman, D. (ed.).

1996. Water quality assessments. A guide to use of biota, sediments and water in environmental monitoring. UNESCO/ WHO/UNEP. Published by E \& FN Spon, an imprint of Chapman \& Hall, Cambridge University Press. 2nd Edition. Great Britain. 9 p.
Coronel, J.S.; Declerck, S.; Brendonck, L.

2007. High-altitude temporary pools in Bolivia house a high cladoceran diversity. Wetlands, 27: 1166-1174.

De Los Ríos, P.

2005. Richness and distribution of zooplanktonic crustacean species in Chilean Andes Mountains and Southern Patagonia shallow ponds. Polish Journal of Environmental Studies, 14: 817-822.

De Los Ríos, P.; Crespo, J.E.

2004. Salinity effects on the abundance of Boeckella poopoensis (Copepoda, Calanoida) in saline ponds in the Atacama Desert, Northern Chile. Crustaceana, 77: 417-423.

De los Ríos-Escalante, P.; Meruane, J.; Morales, M.C.; Rudolph,

E.; Fuentealba, C.; Boxshall, G.

2013. Zoogeography of Chilean inland water crustaceans. Latin American Journal of Aquatic Research, 41: 846-853.

Declerck, S.A.J.; Coronel, J.S.; Legendre, P.; Brendonck, L.

2011. Scale dependency of processes structuring metacommunities of cladocerans in temporary pools of High-Andes wetlands. Ecography, 34: 296-305.

Dejoux, C.

1993. Benthic invertebrates of some saline lakes of Sud Lipez Region, Bolivia. Hydrobiologia, 267: 257-267.

Dorador, C.; Pardo, R.; Vila, I.

2003. Variaciones temporales de parámetros físicos, químicos y biológicos de una lago de altura: el caso del Lago Chungará. Revista Chilena de Historia Natural, 76: 15-22.

Echaniz, S.; Vignatti, A.; José de Paggi, S.; Paggi, J.; Pilati, A. 2006. Zooplankton seasonal abundance of south American saline shallow lakes. International Review of Hydrobiology, 91: 86-100.

Fiebig-Wittmaack, M.

2014. Aspectos del Clima de la Cuenca del río Elqui: Pasado, Presente y Futuro. Editorial Universidad de La Serena, La Serena, Chile, $38 \mathrm{p}$.

Florencio, M.; Serrano, L.; Gómez-Rodríguez, C.; Millán, A.; Díaz-Paniagua, C.

2009. Inter and intra-annual variations of macroinvertebrate assemblages are related to the hydroperiod in Mediterranean temporary ponds. Hydrobiologia, 634: 167-183.

Frisch, D.; Green, A.J.

2007. Copepods come in first: rapid colonization of new temporary ponds. Fundamental and Applied Limnology, 168: 289-297.

González, A.

1988. El plancton de las aguas continentales. CECSA, México, $130 \mathrm{p}$.

Hart, E.A.; Loworn, J.R.

2005. Patterns of macroinvertebrate abundance in inland saline wetlands: a trophic analysis. Hydrobiologia, 541: 45-54.

Jeffries, M.J.

2008. The spatial and temporal heterogeneity of macrophyte communities in thirty small, temporary ponds over a period of ten years. Ecography, 31: 765-775.

Jeffries, M.J.

2011. The temporal dynamics of temporary pond macroinvertebrate communities over a 10 -year period. Hydrobiologia, 661: 391-405. 
López, P.L.; Auqué, L.F.; Garcés, I.; Chong, G.

1999. Características geoquímicas y pautas de evolución de las salmueras superficiales del Salar de Llamará, Chile. Revista Geológica de Chile, 26: 89-108.

Makoto, O.; Tsutomu, Y.

1976. Methods in marine zooplankton. John Willey \& Sons. New York. U.S.A., 332 p.

Márquez-García, M.; Vila, I.; Hinojosa, L.F.; Méndez, M.A.;

Carvajal, L.; Sabando, M.C.

2009. Distribution and seasonal fluctuations in the aquatic biodiversity of the southern Altiplano. Limnologica, 39: 314-318.

Oertli, B., Cereghino, R.; Hull, A.; Miracle, R.

2009. Pond conservation: from science to practice. Hydrobiologia, 634: 1-9.

Oliver, D.R.; Dillon, M.E.

1997. Chironomids (Diptera: Chironomidae) of the Yukon arctic North Slope and Herschel Island. In: Insects of the Yukon. Danks, H.V.; Downes, J.A. Biological Survey of Canada (Terrestrial Arthropods), Ottawa. pp. 615-635

Osorio, R.; Cabezas, R.; Reyes, H.; Álvarez, P.; Koné, T.

2006. Humedales altoandinos de la IV Región. In: Geoecología de los Andes desérticos. La alta montaña del Valle del Elqui. Cepeda-Pizarro, J. (ed.). Ediciones Universidad de La Serena. La Serena, Chile, pp. 153-239.

Oyarzún, R.; Lillo, J.; Higueras, P.; Oyarzún, J.; Maturana, H. 2004. Strong arsenic enrichment in sediments from the Elqui watershed, Northern Chile: industrial (gold mining at El Indio-Tambo district) vs. geologic processes. Journal of Geochemical Exploration, 84: 53-64.

Ringuelet, R.

1962. Ecología acuática continental. Eudeba Editorial Universitaria de Buenos Aires, Argentina. 138 p.

Schwartz, S.S.; Jenkins, D.G.

2000. Temporary aquatic habitats: constraints and opportunities. Aquatic Ecology, 34: 3-8.
Squeo, F.A.; Veit, H.; Arancio, G.; Gutiérrez, J.R.; Arroyo

M.T.K.; Olivares, N.

1993. Spatial heterogeneity of high mountain vegetation in the andean desert zone of Chile $\left(30^{\circ} \mathrm{S}\right)$. Mountain Research and Development, 13: 203-209.

Squeo, F.A.; Ibacache, E.; Warner, B.; Espinoza, D.; Aravena, R.; Gutiérrez, J.R.;

2006a. Productividad y diversidad florística de la vega Tambo. Cordillera de doña Ana. In: Geoecología de los Andes desérticos. La alta montaña del Valle del Elqui. CepedaPizarro, J. (ed.). Ediciones Universidad de La Serena. La Serena, Chile, pp. 325-351.

Squeo, F.A.; Warner, B.G.; Aravena R.; Espinoza, D.

2006b. Bofedales: high altitude peatlands of the central Andes. Revista Chilena de Historia Natural, 79: 245-255.

Tabilo, E.

2006. Avifauna del humedal Tambo-Puquíos. In: Geoecología de los Andes desérticos. La alta montaña del valle del Elqui. Cepeda-Pizarro, J. (ed.). Ediciones Universidad de La Serena. La Serena, Chile, pp. 355-379.

Timms, B.V.

1983. A study of benthic communities in some shallow saline lakes of western Victoria, Australia. Hydrobiologia, 105: 165-177.

Veit, $\mathrm{H}$.

1993. Upper quaternary landscape and climate evolution in the Norte Chico: an overview. Mountain Research and Development, 13: 138-144.

Villalobos, L.

2006. Estado de conocimiento de los crustáceos zooplanctónicos dulceacuícolas de Chile. Gayana, 70: 31-39.

Williams, W.D.

1996. Environmental constraints in temporary fresh waters and their consequence for the insect fauna. Journal of the North American Benthological Society, 15: 634-650.

Zavala, $\mathrm{H}$

2006. Hidrología del humedal Tambo-Puquíos. In: Geoecología de los Andes desérticos. La alta montaña del valle del Elqui. Cepeda-Pizarro, J. (ed.). Ediciones Universidad de La Serena. La Serena, Chile, pp. 287-321. 